\title{
The Russian Bear and the Revolution: The Bear Metaphor for Russia in Political Caricatures of $1917-1918^{\star}$
}

\author{
A. de Lazari', ${ }^{1,}$, O. V.Riabov ${ }^{3}$, M. Zakowska ${ }^{2}$ \\ ${ }^{1}$ Association "Bridges within Europe", \\ 17-2, Niska str., Lodz, 92-332, Republic of Poland \\ ${ }^{2}$ University of Lodz, \\ 65, Narutowicza str., Lodz, 90-131, Republic of Poland \\ ${ }^{3}$ St. Petersburg State University, \\ 7-9, Universitetskaya nab., St. Petersburg, 199034, Russian Federation
}

For citation: Lazari, Andrzej, de, Oleg Riabov, and Magdalena Zakowska. "The Russian Bear and the Revolution: The Bear Metaphor for Russia in Political Caricatures of 1917-1918”. Vestnik of Saint Petersburg University. Arts 9, no. 2 (2019): 325-345. https://doi.org/10.21638/spbu15.2019.206

Using an analysis of satirical journals published in Russia, Germany, Great Britain, and Poland in 1917-1918, this paper explores how caricaturists employed the metaphor of the bear to represent revolutionary events in Russia. The first part of the paper characterizes historical and intellectual contexts for the use of the image of the Russian bear in Western and Russian cultures. Then, the authors discuss how European caricaturists exploited this image to shape perceptions of the Russian revolution. The final part of the article focuses on employing the bear metaphor in Russian satirical journals. The authors point out that the use of the bear was a part of struggle for interpreting Russia's revolutionary events, and this struggle was carried out in no small part in caricatures. It contributed to shaping representations of delegitimating power, domestic political struggle in Russia, substantiation of national character in the revolution, and its influence on Russia's participation in the Great War and on the independence of Poland. The polysemy of the bear symbol provided the possibility to exploit it both for support of the revolution and its criticism. Representations of the revolution through the prism of the bear metaphor varied by political orientation of journals, the country represented, and political dynamics during the period under consideration. There was one commonality: this metaphor was used to symbolize Russianness in both positive and negative meanings.

Keywords: the "Russian bear", political symbols, caricature, satirical magazines, metaphor, the February Revolution of 1917, the October Revolution of 1917, the image of Russia.

\section{Introduction}

The development of the caricature as an art genre is determined both by artistic and social factors. As it is emphasized in many works, caricature by its very nature is connected to social criticism. Lawrence Streicher asserts that caricatures are aimed at dramatizing aggressive tendencies through the definition of targets, the collective integration of "private" feelings into public sentiments of "self-defense," and the training of hatred and

\footnotetext{
* The reported study was funded by RFBR according to the research project № 19-011-00748 A.

(c) Санкт-Петербургский государственный университет, 2019
} 
debunking techniques $[1, \mathrm{p} .438]^{1}$. In Boris Vipper's opinion, caricatures are in greatest demand during social upheavals, as well as at economic and political turning points [2]. It also plays a significant role in revolutions, and from this perspective we discuss caricature during events that occurred one hundred years ago in Russia - the Revolution of 1917, the beginning of the Civil war, the dissolution of the Russian Empire, and the emergence of independent states in the twentieth-century Europe.

In this paper, we focus on how caricaturists portrayed revolutionary events using the metaphor of a bear for Russia. Ernst Gombrich argues that metaphor is a common and expected device in political cartoons: it is one of the main "weapons" in the "cartoonist's armory." In his opinion, "the cartoonist can mythologize the world of politics by physiognomizing it. By linking the mythical with the real he creates that fusion, that amalgam, that seems so convincing to the emotional world. $<\ldots .>$ The cartoonist's armoury is always there in the workings of our mind. $<\ldots>$ Contrasts such as light and shade, beautiful and ugly, big and small, which form the coordinates of the cartoonist's mythical universe, would not be so effective if we all were not inclined to categorize the world around us in such basic emotional metaphors" [3, p. 139-40].

Thus, the aim of the paper is to analyze how caricaturists in Russia and Europe employed the image of the Russian bear to represent reasons for the Revolution of 1917, its course, participants, and expected outcomes. Our main research questions are: How was the bear metaphor included in caricaturists' assessment of the revolution, especially its legitimation or discreditation? What themes, associated with the poetics of the bear, did caricaturists use to depict revolutionary events? How was this exploitation of the "Russian bear" correlated with other ways of representing the revolution? How did the image vary by political orientation of the journals, the country that it represented, and political dynamics during the period under consideration - 1917-1918, from the February Revolution to the dissolution of the Russian Empire and declaration of independence by many outlying ethnic regions?

To choose representative cases, we use caricatures published in satirical journals from different countries: Russia (Novyi satirikon, Budulnik, Bich, Strekoza, Trepach, Baraban; Pugach, Iskry; Krasnaia kolokol'nia, Gilotina, Krasnyi d'iavol, Solovei, and Grubian); Germany (Der Wahre Jacob, Kladderadatsch) as her adversary in the Great War; Great Britain (Punch) as an ally; and Poland (Mucha, Sowizdrzał, Szczutek) as a country that became independent during the war and revolution.

\section{The bear metaphor for Russia in the Western and Russian cultures: Historical context}

Although the bear is often called the unofficial symbol of Russia, the bear as a metaphor for the country is largely a Western "invention." Comparing Russia with a bear goes back to the sixteenth century. Later it occupied an important place in representations of the country, appearing in travelers' accounts, political rhetoric, and graphics. For example, in his Letters on Russia (1759), the Italian Francesco Algarotti likened Russia to "an enormous polar bear, standing with his rear paws on the shore of the Arctic Ocean, with

${ }^{1}$ Streicher points out that the caricaturist defines or chooses an enemy and attacks that enemy by ridicule. Analogically, the caricature itself aims at passionate, partisan, mass reading publics and is naturally designed to organize mass aggression and hostilities [1, p.433]. 
his tail lowered into the water, his snout pressing against Turkey and Persia, and his front paws stretched to the West and East" [4, p. 65]. Algarotti cited European politicians who warned those thinking of teasing the bear and recalled Charles XII of Sweden, who started to torment the wild beast, which resulted in part of his state being swallowed and turning into the horror of Europe.

In the nineteenth and twentieth centuries, outstanding representatives of Western cultures, including famous writers, artists, medalists, sculptors, journalists, and directors, used the image of the Russian bear in their works. The placing of this image in newspapers and satirical maps, postcards and stamps, medallions and toys, movies and animated films indicated its significance [on the history of the image of the Russian bear see: 5]. The special role in popularizing this image belongs to caricatures with the Russian bear, the first of which appeared in the 1730s [6].

For interpreting the main traits and functions of that metaphor, one should take into account that it emerged when the image of a bear as such had strong negative connotations in Western Europe [7-10]. In analyzing the functions performed by the uses of metaphor, we should note above all a cognitive function: comparing Russia to a bear creates the connotation of a big, strong, and potentially dangerous country. The metaphor contributed to ascribing Russians traits, which modernity discourse used to mark as Otherness, including barbarity, backwardness, laziness, sluggishness, inability to progress, and unpredictability ${ }^{2}$. Lastly, the use of the bear metaphor was often intended to accentuate aggressiveness as a characteristic of the country. For instance, Winston Churchill talked of "the murderous paws of the Russian bear" [12, p. 161], and Karl Marx wrote that "the Russian bear is certainly capable of anything, so long as he knows the other animals he has to deal with to be capable of nothing" [13, p. 172-3]. This image has also positive connotations; not only rivals but also allies kept in mind the strength of the bear [5]. However, the main feelings that the Russian bear evoked among Western observers were belief in their own civilizational superiority, fear and respect for its enormous power, apprehension of awakening a ferocious predator, and a desire to tame it or even chain it up.

Another function connected to constructing European identity is that the Russian bear served as a "symbolic border guard." The identity of Europe was dependent in no small degree upon Russia's exclusion $[14 ; 15]^{3}$ and this symbol evidently played an important role in substantiating propositions regarding both the Otherness of Russia and her inferiority, contributing significantly to drawing symbolic boundaries between "civilization" and "barbarity" [17]. As Peter Møller notes, "Russians were constructed as body and nature, whereas Europeans were constructed as mind and civilization. Enlightenment discourse at large clearly drew on such a dichotomy, and this seems to be a locus from which arose the metaphor of the Russian ursa major, the metaphor that is still very much present in European discourse in its delatinized form" [quoted in: 15, p. 80]. In Western authors' eyes, Europeanness was only a semblance of the Russian bear, which was fatally incapable of progress. Gottfried Wilhelm Leibniz called Russians "the baptized bears" [quoted in: 18, p.36], while the leitmotif of marquis Astolphe de Custine's book Russia in 1839 was that "the Russians are a nation of imitators." The French author wrote that the Russians had

${ }^{2}$ We share Jason Dittmer's observation that the connotations of the bear metaphor (barbarity, mindlessness, irrationalism, and the necessity to be controlled by the West) are typical for the discourse of Orientalism [11, p. 170].

3 Though Western discourse on Russia is certainly neither invariable nor homogenous [see: 16]. 
"just enough of the gloss of European civilization to be 'spoiled as savages', but not enough to become cultivated humans. They were like 'trained bears who made you long for the wild ones"' [19, p. 347].

Further, the bear metaphor served as one tool for political struggle. Accusations of political adversaries in pro-Russian sympathy were supported sometimes by portraying them in a bear guise (say, British communists portrayed as a bear-cub in a cartoon published in 1924 in Punch [I]). Finally, the bear metaphor, by arousing fear, helped substantiate certain politics towards Russia and the USSR. It is hardly surprising that wartime propaganda machines exploited this metaphor to support military conflicts with Russia, from the Napoleonic Wars to the Crimean War, the Russo-Japanese War, and both world wars to the Cold War, as well as the military conflicts of the twenty-first century [20;6].

The discourse of the First World War was no exception. The war was waged on the pages of newspapers with equal ferocity: exploiting national phobias and stereotypes, the propaganda of all countries used animal metaphors, and the Russian bear occupied a visible place in this "menagerie of the nations." The images of the Russian bear were embellished on the pages of the best magazines of these times, including Punch, Jugend, and Simplicissimus. The popularity of animal metaphors also benefited from the important role played in World War I propaganda by caricature, which usually serves as a "launch vehicle" for this sort of imagery [22, p. 163-92].

During the Great War, Russian propaganda also actively exploited the bear metaphor, including in satirical graphic art ${ }^{4}$ - although to a significantly smaller extent than propaganda of European powers. It should be noted that, contrary to current beliefs, the bear was not a symbol with which Russians identified themselves and their country "since primordial times." In Russian culture, the image of the bear was ambivalent, embodying negative features no less than positive ones. It was not surprising that in "high culture" of the Russian Empire - among writers, philosophers, and artists - there is no evidence of respectful attitudes towards bears, much less identifying it with Russia.

As studies of Russian satirical journals for the 1905 Revolution show, the image of the bear emerged as a political symbol by the turn of the twentieth century. There are a number of factors that led to the politicization of this image: its prevalence in Russian culture; the increased influence of Western satirical cartoons, where the image of the bear had long acquired the status of an allegory of Russia; democratization of political discourse, which required easy-to-understand images for a wider audience; and the emergence of a large number of satirical magazines. Finally, another factor was the revolutionary movement of the early twentieth century, which used a variety of resources, including symbols. The use of the bear became part of the symbolic struggle for delegitimizing authoritarian power by left-wing journals, or, on the contrary, discrediting the revolution by the right-wing ones. Alongside differences in their interpretations of the semantics of the bear symbol, the left- and right-wing journals also had a common feature: the symbol of the bear was used to represent Russianness, with both positive and negative features. Additionally, the Russian bear was definitely not the most prominent character of revolutionary discourse, and it was more easily found in the pages of Western magazines than in those in Russia.

${ }^{4}$ For instance, during the war more than three dozen "bear" caricatures were published in Budil'nik, Novyi Satirikon, Bich, and Osa, as well as in newspapers Novoe vremia and Birzhevye vedomosti [5;22]. 


\section{The Bear and the revolution in German, British and Polish satirical discourses}

We will focus only on the presence of the Russian bear in satirical discourse expressed in representative German, British, and Polish journals. Their list and short description are given in the table below.

\begin{tabular}{|c|c|c|}
\hline \multirow{3}{*}{ 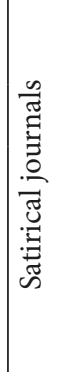 } & German & $\begin{array}{l}\text { Der Wahre Jacob - a magazine representing social-democratic views }{ }^{5} \text {. } \\
\text { Kladderadatsch - a magazine with a right-conservative lean }{ }^{6} \text {. }\end{array}$ \\
\hline & British & Punch - renowned liberal-conservative journal ${ }^{7}$. \\
\hline & Polish & $\begin{array}{l}\text { Mucha - a right-nationalist magazine (in } 1917 \text { published in Moscow, in } 1918 \text { in } \\
\text { Warsaw) }^{8} \text {. } \\
\text { Sowizdrzat - a magazine with a center-left lean (published in Warsaw, in the } \\
\text { German-controlled Kingdom of Poland) } \\
\text { Szczutek - a magazine representing center-left views (published in Lviv, in Austria- } \\
\text { Hungary) }{ }^{10} \text {. }\end{array}$ \\
\hline
\end{tabular}

To systematize the multitude of narratives connected to this metaphor, we summarized them into three main motives. In addition, the analysis presents the degree to which these motives were reflected in German, British, and Polish satirical discourses.

\section{The bear in a Phrygian cap}

First, we can recognize the motif of the bear as a metaphor for Russian national resistance: both against authoritarian rule (the bear as a symbol of the oppressed people) and wartime enemies (the bear as a symbol of the republican army and government after the February Revolution). Furthermore, the mentioned figure was enriched with a new element soon after the Tsar's abdication: the Russian bear was wearing the Phrygian cap, a symbol of the people's victory. At first glance, this motive was giving a neutral connotation, because it could simply be treated as a symbol of the republican government. Thus, it would inscribe on the Russian revolution the tradition of great uprisings, personified by the figure of Marianne. However, this symbol also contains another message. The image of a bear in a Phrygian cap carried a partly ironic, and partly alarming, content. Alarming, because it can be regarded as an allusion to the Great Terror of the French Revolution, and because of associations with Russian expansionism hidden behind Messianic slogans. Ironic, because freedom leading the people to the barricades was shown

${ }^{5}$ Der Wahre Jacob was published in Hamburg and later in Stuttgart from 1879 to 1933. During World War I it reached a circulation of over 160,000 copies.

${ }^{6}$ Kladderadatsch was published in Berlin from 1848 to 1944. During World War I it reached a circulation of over 40,000 copies.

7 Punch or, The London Charivari was published in London from 1841 to 1992 and from 1996 to 2002. It reached a circulation of 100,000 copies in 1910. Punch became a staple for British drawing rooms because of its sophisticated humor and absence of offensive material, especially when viewed against the satirical press of the time. Historian Richard Altick writes, "To judge from the number of references to it in the private letters and memoirs of the 1840s $<\ldots>$ Punch had become a household word within a year or two of its founding, beginning in the middle class and soon reaching the pinnacle of society, royalty itself" [23, p. 17].

8 Mucha was a Warsaw satirical magazine published from 1868 to 1939 and from 1946 to 1952.

9 Sowizdrzat was a Warsaw satirical journal published from 1911 to 1914, 1915-1919, and 1927-1928.

10 Szczutek was published from 1869 to 1896 and from 1918 to 1929 [24, p. 188]. 


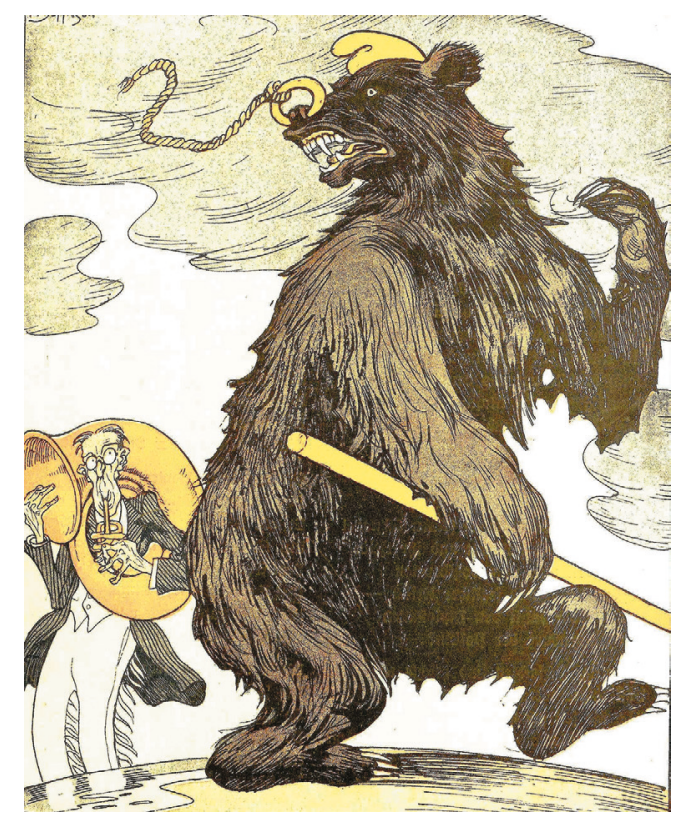

Fig. 1. Johnson, Arthur. "Wilsons Botschaft". Kladderadatsch 26 (1917)

with a bear's face. In this context, we can recall a Spanish caricature from the magazine Esquella de la Torratxa from March 23, 1917, showing a white bear in front of a mirror, saying: "How beautiful I am! Phrygian cap suits me well" [25]; and a German caricature, published in the journal Kladderadatsch on June 30,1917, depicting a beast in a Phrygian cap with a cattle nose ring and a stick in its paws, which contemptuously refuses to dance to President Woodrow Wilson's message (fig. 1).

Nevertheless, an analysis of the latter drawing suggests that the revolutionized, rebellious Russian bear was also seen in a positive light. The aforementioned caricature was an allusion to the negative reaction of Russian government to the Fourteen Points proposed by the President of the United States. Hence, in this caricature we observe the German gesture of specific solidarity with the Russian bear. Russia, as suggested, was not going to dance to anyone's tune, but to do politics on her own ${ }^{11}$.

When the German hopes for peace with Russia’s Provisional Government led by Aleksander Kerenskii faded, German satirists began to identify the Russian bear with the opponents of the White Movement, because it was the Bolsheviks who proclaimed the slogan of an immediate "peace without annexations and contributions." This state of affairs was reflected in a caricature published in August 1917 in the social democratic magazine Der Wahre Jacob (fig. 2). The picture, entitled ironically "The fight for peace,"

11 Wilson treated them as indispensable conditions that should be met to ensure peace and justice in post-war Europe. These proposals included creating an international order based on the right to selfdetermination of nations, including the creation of an independent Polish state with access to the sea. Germans perceived these - not without reason - as aimed primarily at the German Empire. The intention of the American president was also to support democratic forces in Russia against the Bolsheviks and to urge the country not to conclude a separate peace peace with Germany. 
Dex Sampf um Den Frieden in Ruß̃land.

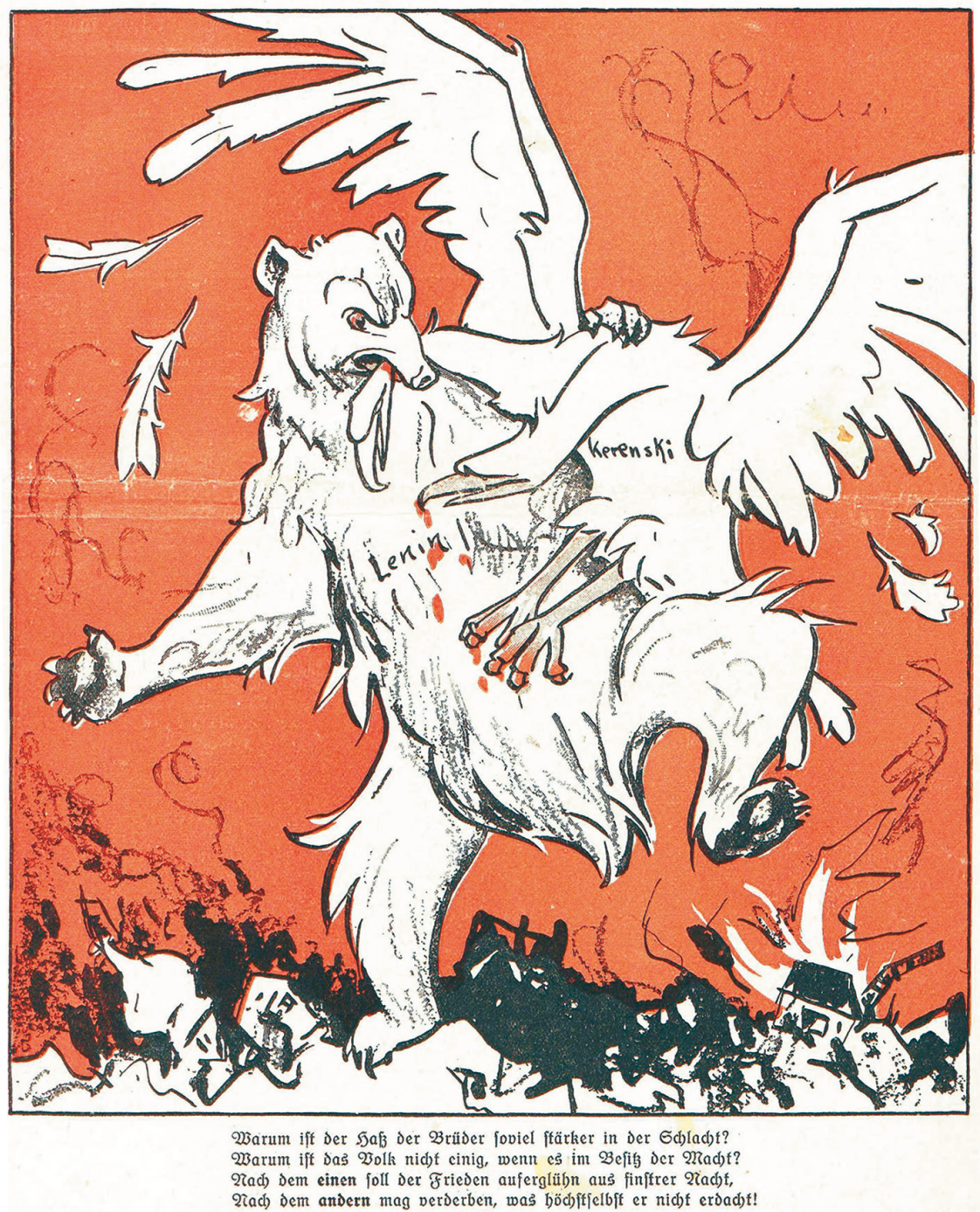

Fig. 2. "Der Kampf um den Frieden in Rußland". Der Wahre Jacob 819 (1917)

presents a struggle between the Russian government and the Bolsheviks as a bloody clash of the bear-Lenin with the two-headed eagle-Kerenskii. The enraged bear keeps one of the eagle's heads in his mouth, and the eagle scratches him with its beak and claws. The bear is trampling the people and destroying burnt houses with a kick. In this context, it is difficult to recognize it as a positive hero. To understand the message hidden in this caricature, however, it is more important to stress that the cartoonist: 1) while confronting an eagle with a bear, in the first figure visualized the new-old regime, and in the second one "the voice of the people"; and 2) made Bolsheviks the representatives of common Russians.

On the other hand, the picture condemns the cruelty of the Russian civil war, which can be easily seen in the following commentary, situated below the caricature: 
Warum ist der Haß der Brüder soviel stärker in der Schlacht?

Warum ist das Volk nicht einig, wenn es im Besitz der Macht?

Nach dem einen soll der Frieden auferglühn aus finstrer Nacht,

Nach dem andern mag verderben, was höchstselbst er nicht erdacht! ${ }^{12}$

Interestingly, British caricatures presented mirror images in comparison to the German cartoons. For instance, the cartoonist from Fliegende Blätter presented a bear which after the revolution recognised his true interests and chased the British lion away ${ }^{13}$, and a cartoonist from Punch presented a bear that broke the fetters of German influence and got back on the right path (which we can assume was a strict alliance with the Entente (fig. 3).

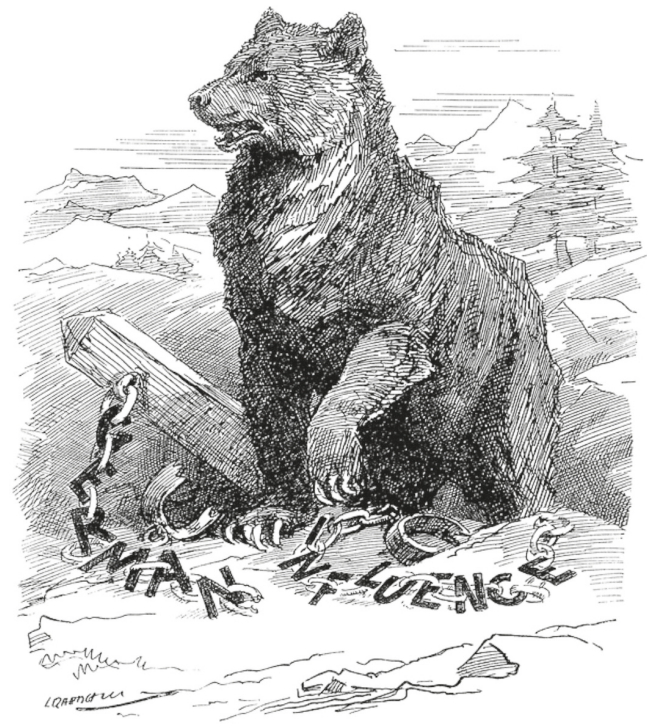

THE BREAKING OF THE FETTERS.

Fig. 3. "The breaking of the fetters", Punch, March 21, 1917

Another important feature of British and European liberal and right-wing satire in general was the fact that it tended to ignore revolutionary attributes of the Russian bear figure. For example, the caricature "The Brusiloff hug," which refers to Kerenskii's offensive in the summer of 1917 and presents General Brusilov under the shape of the bear smashing the German emperor in a "brotherly" hug (fig. 4), resembles a drawing from 1916, in which the Russian bear - the same General Brusilov — is using a crushing embrace against a General of the Austro-Hungarian army [II]. The bear from 1917 is in the service of a new, revolutionary government, but he is wearing the same soldier's headgear, not the Phrygian cap, lying next to him on the ground.

${ }^{12}$ Why is the hatred between the brothers growing as the battle continues? / Why aren't the people united when they are finally in power? / Now, when peace should build our future heaven, / Why is this country again on its road to perdition! [translation Z. Piwowarska].

13 Sf. caricature of a white bear that refuses to dance to the music of British bagpipe, published in "Sowizdrzal" on March 18, 1917 [II]. 


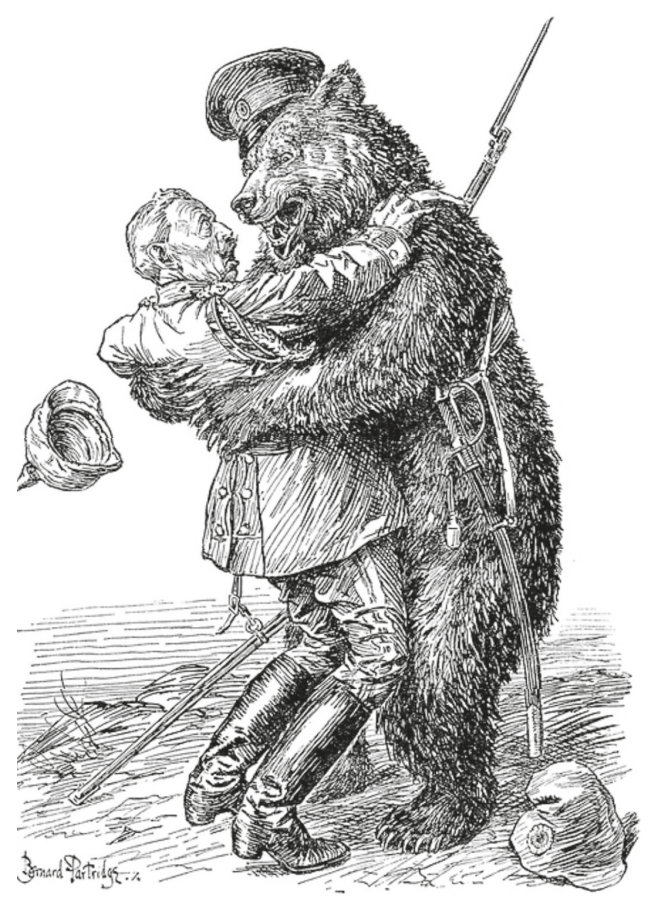

THE BRUSILOFF HUG. 1917

Fig. 4. "The Brusiloff hug", Punch, July 11,

We can also trace a motif of hostility between the Russian bear and the Bolsheviks in the English satirical press, which was intended to illustrate the anti-Russian character of the communist regime. However, in this narrative the satirists of Punch preferred to use an another symbol of Russianness than a bear. The tragic fate of this country was usually shown with a metaphor of wicked, brutal Bolshevik robbers and of a beautiful, defenseless Mother Russia [IV; see also: 26, p. 93].

Summing up, we may conclude that the above-mentioned narrative contained mixed, ambivalent content. On the one hand, it was aimed at emphasizing the strength of revolutionary politics and forces. On the other hand, the furious Russian bear, as seen in the cartoons, could hardly be considered as a metaphor legitimizing Russian or any other revolutionary slogans.

\section{The "sleeping" bear}

A second use of the Russian bear metaphor was as a visualization of Russian observers and victims of revolutionary anarchy and chaos, especially right before and after the October Revolution. A good example of such cartoons are caricatures from Polish satirical magazines. The critical reflection about Russia was even expressed in such magazines as Sowizdrzat and Szczutek, which were published on the German and Austro-Hungarian territories after the treaty of Brest-Litovsk. For instance, a picture from Sowizdrzat entitled "History has time" shows a bear standing on the former Tsar's pedestal. Nevertheless, there is a red loop squeezing around his neck, pulled by a dark figure we can observe 


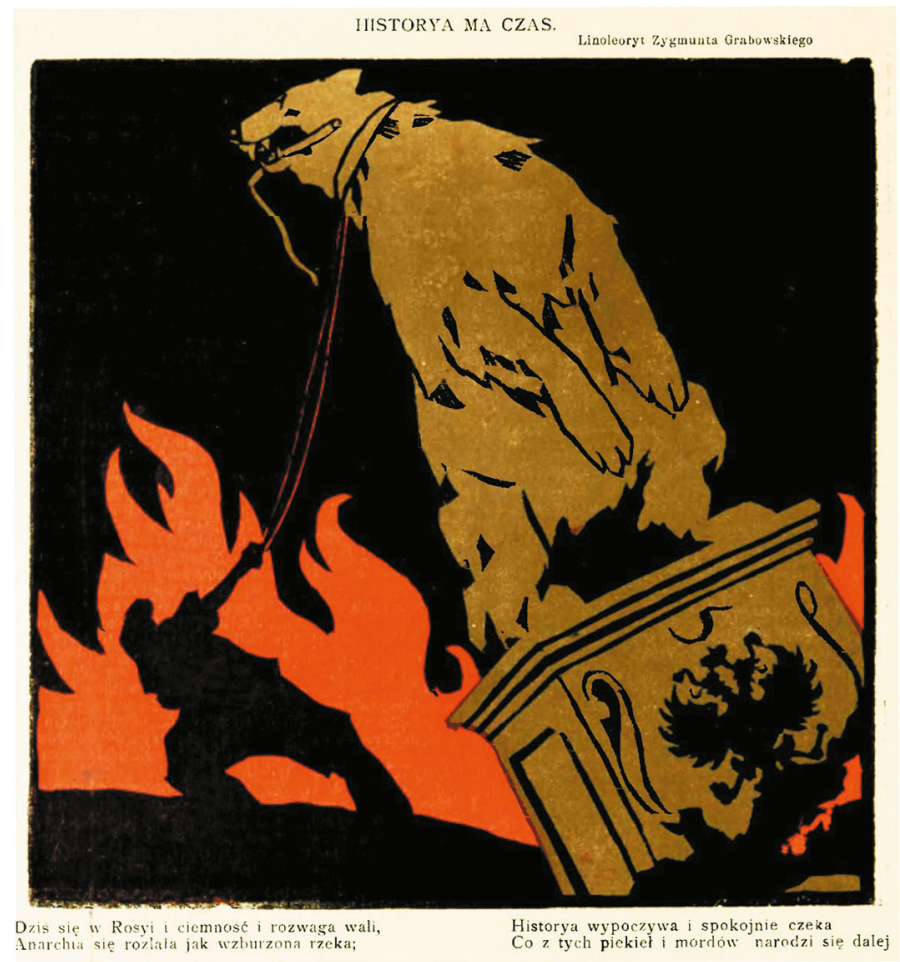

Fig. 5. Grabowski, Zygmunt. "Historya ma czas", Sowizdrzał, September 30, 1917

in the background, next to a spreading fire (fig. 5). The (Bolshevik's?) loop is just going to overthrow the stone pedestal and the bear (also made of stone?) standing on it. The giant beast bares its teeth, which are holding the knout, but otherwise remains motionless. The inscription below the illustration says:

"Dziś się w Rosyi i ciemność i rozwaga wali,

Anarchia się rozpala jak wzburzona rzeka;

Historya wypoczywa i spokojnie czeka,

Co z tych piekieł i mordów narodzi się dalej”"14.

Sympathy towards the Russian people was more clearly expressed in Szczutek. Censorship often influenced the content of this journal, because it was very critical of the Austrian wartime reality. Russian topics were also often emphasized there and, interestingly, they often appear in an anti-German context. For example, there were clear suggestions that the treaty of Brest-Litovsk resulted in the robbery of already limited Russian resources. However, journalists first of all tended to insinuate that it was the Allies, the White Movement, and Jews that should had been blamed for Russia's distress [V]. For instance, in a caricature of May 15, 1918 we can see a huge but meek bear, walked by a White Guardist (?) [VI]. The picture is followed by a verse:

14 "There is a dark time in Russia, / Anarchy is growing and raged like a storm; / History rests and is calmly awaiting, / What out of this hell and murders is going to be born" [translation M. Żakowska]. 
"Rzekł cygan do niedźwiedzia: świat się myli srodze,

Twierdząc z oburzeniem, że cię za nos wodzę”.

Sometimes, however, the content of Szczutek's articles carried ambiguous, universal messages. Who should be identified as the main character in the poem about animals that used to live a miserable life in a zoo, but managed to free themselves at the end of the story? The Romanov Empire, or perhaps the multinational Habsburg monarchy, which in this period was also experiencing decline? [VII] ${ }^{15}$.

It is worth noting that during the first two years of revolutionary Russia, Polish cartoonists did not tend to call this country Poland's enemy. In the satirical press soon before and soon after the Republic of Poland was established, there was a lot of concern about the weakness and possible disintegration of Russia, rather than the Russian military threat. Also interesting is the absence of anti-Semitic threads [See: VIII] ${ }^{16}$.

An interesting example of satire aimed at the Bolsheviks, but not at Russia, is from the weekly magazine Mucha. A strong emphasis was made there on the events of the Russian revolution, and its course was observed - as we may conclude from the articles - with the concern that the approaching decline of Russia would mean the hegemony of German Empire. Numerous caricatures published in this magazine showed a so-called typical Russian man, "Ivan." He used to be presented as a kind of "stupid Hansel," a popular character from European (and Russian) fairytales: a simpleton who had been manipulated by revolutionary anti-war propaganda, excessively pleased with himself, who did not want to notice Russia's military failures. In this context, we may assume that the Russian bear, as a symbol of the suffering, confused, and manipulated Russian people, used to carry a pessimistic message. This figure was clearly aimed at delegitimizing both Russian revolutionary slogans and Bolshevik foreign policy. On the other hand, the use of the bear metaphor evidently suggested that the authors of caricatures perceived the Russian nation as not mature enough for democracy, or even for their own country's independence.

It is important to stress that a common feature in images of Russia shared by the nationals of both the central powers and Entente was the conviction that Russia only partially belonged or did not belong to Europe and European civilization ${ }^{17}$. Before 1917, the

15 The capture below: "W pewnej wielkiej menażerii / Wegetował zwierz wszelaki / W nieopisanej mizerii / Z głodu aż mu spuchły flaki... / A im krwawsze zbiera baty, / Im dotkliwiej los go bodzie, / Tem gwałtowniej spoza kraty / Rwał się, skomląc ku swobodzie. / Aż raz wyszło prawo Boże. / Że się kruszą wszelkie pęta / I na wolność w każdej porze / Mogą sobie iść zwierzęta. / Pękły klatek więc zamczyska, / A pan menażerii onej / Widzi jak się trzoda ciska / I rozbiega na wsze strony. / Trzodo moja (westchnie z cicha) / Cóż się teraz ze mną stanie? / A lew na to: / - Tam do licha! / O tem... nie myślelim, panie...”

16 The capture below: "Dla swej nicości szukał sił w pożodze, / A nawet krwią się umaczał monarchy... / Nic nie pomogło... Los go dotknął srodze... / Zmarł na angielską chorobę i parchy." Anti-Semitic statements started to emerge, as we can assume, in reaction to the revolutionary atmosphere in newborn Poland. In the Polish lands, impoverished and destroyed by the war, and characterized by strong social stratification, all responsibility for revolutionary ferment was attributed to Polish Jews accused of supporting the Bolsheviks. It should also be stressed that this propaganda was not accompanied by demonized visions of the notorious Bolszewia (which later was to be used, throughout all 1920s and 1930s), but by a modest slogan of consolidation of the whole Polish nation, personified by the figures of a Polish nobleman, peasant, and worker.

17 This othering was provided with help of various means, including employing the animal metaphor. For instance, caricaturists employed the metaphor of a child; the Polish Mucha published a cartoon that symbolized Russia as a child playing matches. He takes matches from a box labeled "Liberty" [IX]. Among other images used in the satirical discourse on the revolution, one can find traditional symbols of Mother Russia or the Russian muzhik that correlated with the bear metaphor. 
anachronistic nature of the tsarist autocracy was emphasized, as well as Russian backwardness, oppression of peasants, drunkenness, superstition, and illiteracy [14, p. 13070]. After 1917, this image was, at least partly, legitimized by the newly defined Russian bear metaphor. Let us recall some of characteristic traits inscribed on a bear just like on any other animal symbols. A beast is not human. It reacts to events and often gets involved in their course, involuntarily or in self-defense, but it cannot be called their driving force or creator. A bear is also an element of nature: it can be useful, but also unpredictable and dangerous when it gets out of control.

\section{The bear in snares}

A third form was German and Austrian narratives about the bear as a hunted animal, that can be considered as stories about unchangeable, old, giant Russia, attacked yet again by Western great powers. This was, among others, reflected in a caricature from Austrian satirical journal Kikeriki depicting an extremely exhausted Russian bear lying down, which allied countries try to awaken by forcing money into its muzzle and by brutal attempts to roll the bear over onto its feet [X].

After the October revolution, Germany supported the new regime ${ }^{18}$ and condemned the politics of the Entente to overthrow the Bolsheviks. This is clearly seen in a caricature from 1918, which compares Western intervention on the side of the White Movement to the attack a Gulliver tortured by dwarfs. A bear falls on his back in order to smash the aggressors, who are trying to tie up his giant body. The message of the illustration is clear: the struggle between the bear and the robbers from the Entente was presented as the king of the forest trying to get rid of fleas [XII].

This message was clearly different from violent anti-communist propaganda widespread in the mentioned period across Europe. For instance, the British press, in response to the events of the October Revolution, created new symbols, more deprecating than a bear. The most important of these new symbols was a predatory pack of Bolshevik wolves. The bear motifs, on the other hand, contained this time literally no allusions to the revolution, Russian civil war, or any other concpetion that after 1917 Russia was a different country. These signs were obviously not needed because the mentioned cartoons, we can assume, had hardly anything to with the problem of legitimizing the Russian revolution. We suggest, however, that the narrative about the bear under attack served as a tool for legitimizing German and Austrian war propaganda against the Allies.

\section{The bear in Russian political caricature}

Regarding Russian satirical journals, one can discern several aspects the use of the bear to represent revolutionary events. First, the symbol was employed to delegitimate the authoritarian power and to legitimate the revolution. It was also used to assert the national

18 An illustration published in Der Wahre Jacob in January 1918 is an interesting visualization of a new Soviet Russia. Two figures represent the Soviet country: Lenin, stylized as a good-mannered and hospitable man from the Orient, and a cheerful Russian soldier attending a peace concert with representatives of the Central Powers. A positive message of image is enhanced by the fact that it was inscribed on the vision of a magical Christmas Eve night. Its atmosphere consists of the falling snow, three guests (representing the Entente countries) standing by the door, just like the Three Magi, and of an illuminated room where the residents who, just like a good German family, engage in music-making by the fireplace [XI]. 


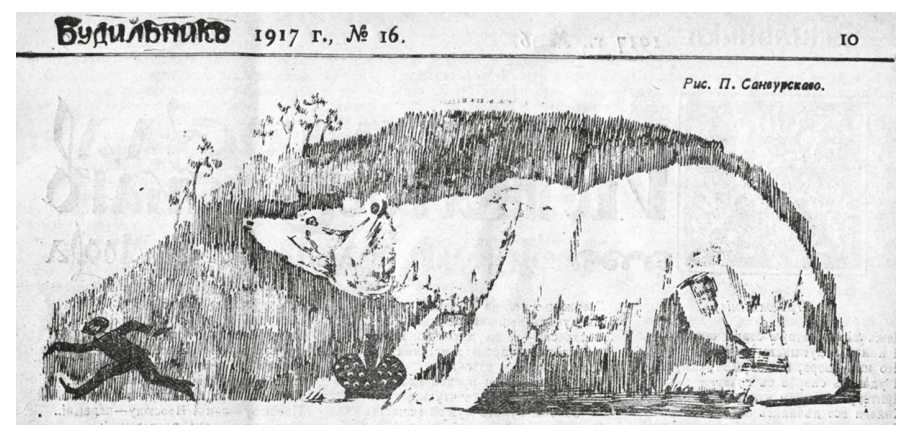

Fig. 6. Sangurskii, P. “<No title>”. Budil'nik 16 (1917): 10

character of the revolution and to connect it to Russia's revolutionary traditions. In addition, it represented foreign politics of Russia, determined, above all, by her participation in the First World War and, finally - domestic political struggle before and after the October revolution in 1917-1918. Let examine these aspects in detail.

The February Revolution, which abolished civil censorship, allowed Russian caricaturists to use a Bear-and-the-Tsar plot. A cartoon from Budil'nik, published in April, shows the tsar fleeing the Bear, symbolizing the revolutionary people [XIII, p. 10] (fig. 6). This is an example of how the image of the bear performed the function of signification, first of all by designating the people (unlike in the Revolution of 1905, when it designated the authorities). The February revolution was represented as "people's revolution," not a class revolution.

In seeking legitimacy, the actors in symbolic politics of the February revolution addressed to the symbolism of revolutions in Western history, above all in France; to demonstrate that events in Russia were akin to a revolutionary movement in the "civilized countries," they exploited such symbols as female allegories of Liberty and Revolution, as well as the image of Russia in antique garments [26]. In all likelihood, Russian caricaturists, unlike their Western counterparts, did not portray the bear in a Phrygian cap (although Russian journals used this element of revolutionary aesthetics in different contexts) ${ }^{19}$.

One more function performed by employing the bear symbol is delegitimating power. Revolutionary discourse represented the autocracy as the enemy of its own people, whose suffering was pictured with the help of "bear" themes: the bear in chains or in a cage; bear baiting; training the bear; and others. For instance, in April 1917 Novyj satirikon published Aleksandr Radakov's caricature "A history of the meek bear and the joyful tsar" (fig. 7). The caricature consists of four scenes; the first three portray the difficult conditions of the people, i.e. the bear under autocracy: the oppressor puts it in a cage, rides it out, coaches it to drink vodka, and boasts of its submissiveness to the foreigners. The fourth scene shows how one fine day it turned out that the bear was not meek, and now the bear and the tsar exchange places.

${ }^{19}$ For example, in 1905 the journal Shut published a caricature representing a worker taking a hat off a woman symbolizing Russia, kokoshnik, offering in return the Phrygian cap. The caricature contains the caption "Get off, you devil $\langle\ldots\rangle$ how is it possible to wear such a cap with the 'sarafan'?" [XIV]. Apparently, the author of the drawing "Making of the union," published in Svistok in the same year, was guided also by the belief that Russia would never become a modern country: it portrays a worker who makes an alliance not with Russia, but Marianne as a symbol of freedom, on whom the Phrygian cap looks more natural [XV, p. 16]. 
Therefore, the use of this symbol aimed to stress that the revolution was just and historically inevitable. We note that the image of the bear has many common traits with another famous symbol, "Mother Russia," which was also used to demonstrate the suffering of the people, to show loss of the authorities' legitimacy, to justify the overthrow of the tsar, and to stress the all-national character of the revolution. The mother symbol of Russia was more visible in revolutionary discourse. For example, a token worn by supporters of the overthrow of the autocratic regime in the first months after the revolution shows the image of the bear with a red flag; however, only one token of such design is known to us. (By way of comparison, of more than thirty variants of tokens, the female allegory of liberated Russia is present in eleven.) [26; see also: 27, p. 360]. Further, there were differences related to gender: while in the image of Mother Russia caricaturists emphasized the suffering of the people, in the image of the bear they accentuated strength.

Exactly as an embodiment of strength, the bear metaphor was included in discourse on foreign politics, especially in representations of the Great War. This was another difference from caricatures of the Revolution of 1905: the bear was increasingly used as a national allegory. The "rehabilitation" of this symbol and Russian self-identification with it can be attributed, in part, to the above-mentioned fact that the propaganda of Entente countries used the image of the bear to represent Allied Russia, ascribing positive features to this country, above all strength. Stressing strength in the image of Russia-the-bear aimed to demonstrate the country's determination to fulfill its commitments to the Allies and her ability to defend revolutionary gains. For example, in April 1917, Bich published a cartoon by Deni, in which a red Bear is warning the Kaiser not to take aggressive actions against revolutionary Russia (fig. 8).

Because the bear was designed to embody patriotism and readiness to prosecute the war with Germany to a victorious conclusion in discourse on foreign politics, at the moment it had anti-Bolshevik connotations, which shaped its exploitation in the discourse of domestic political struggle. Accusations of Vladimir Lenin spying for Germany, reinforced after the "July days" of 1917, were reflected in satirical graphics; for example, the Bolshevik leader was portrayed in an appearance of Jude receiving thirty pieces of silver from the Kaiser [28]. Caricatures in which the Bolsheviks opposed the bear were designed to demonstrate the anti-people nature of Bolshevism and its disregard for national interests. For instance, the journal Pugach published a caricature that portrayed the Bolsheviks as fleas baiting a large polar bear by order of Wilhelm [XVI, p. 5]. In a drawing with a telling title "How is it possible not to help a relative?" published during the Russian offensive in June (the so-called "Kerenskii offensive"), the Russian army is pictured in the guise of the bear who easily eliminates a German soldier, whereas a Bolshevik tries to prevent him from doing so: "Misha, my dear! In doing so you can hurt him!" (fig. 9).

As the revolutionary euphoria gave way to disappointment of the real fruits of the revolution, the context of employing the bear symbol changed. Now "bear traits," ascribed to the people, were bitterly criticized; they were considered as one of the reasons for the failures of the revolution. For instance, the author of a tale published in Bich argues that the Russian bear is not only stupid, like any other bear, but also intemperate: he ate too much freedom, equality, and brotherhood [XVII, p. 14] ${ }^{20}$. The military setbacks also changed the

20 The bear metaphor was used for accusing Russia and Russians of insufficient civility in Marina Tsvetaeva's poem, written after the scourge of revolutions and civil war in 1922. We find the following lines there: "Ved' i medvedi my! / Ved' i tatary my! / Vshami iziedeny / Idem — s pozharami! // Pokamest — v dolg 


\section{ИСТОРІЯ СМИРНАГО МЕДВЬДЯ И ВЕСЕЛАГО ЦАРЯ.}

Puc. A. Paдакова

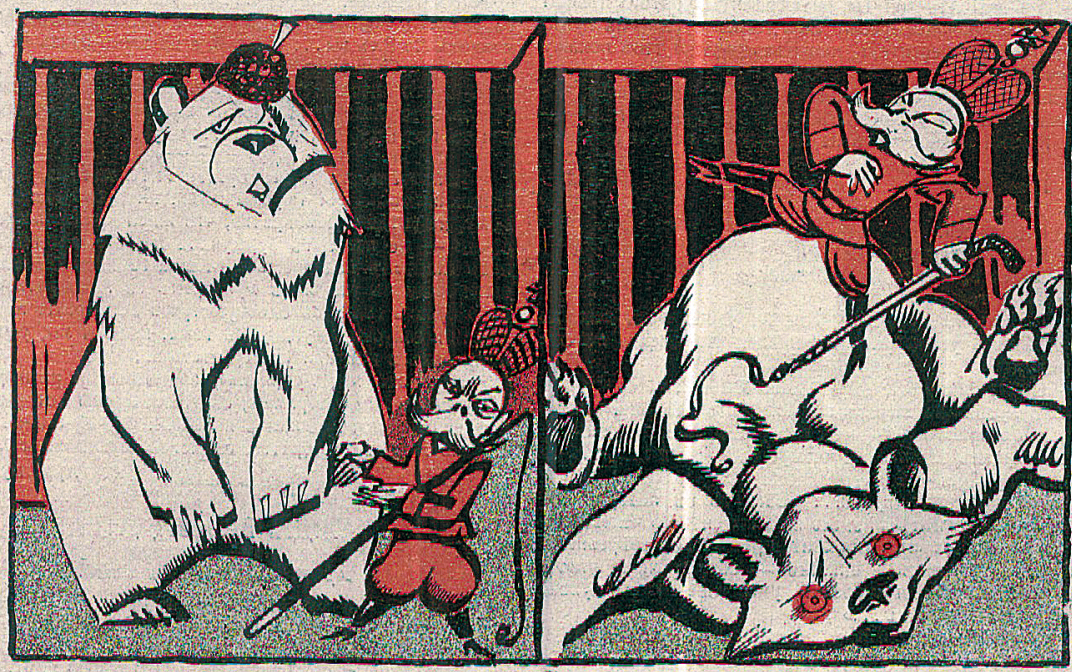

Сначала цобрыи мепввдынлародь быль въ клыткћ, a. Царь на свободы. Haplinia онъ заходилт въ клtтку 4. показываль знатнымъ нностранцамъ: "Какоһ онъ у. меня послушның, этогъ медвьдь"... можно"

„Посмотритекка, на немъ лане верхомъ ьядить

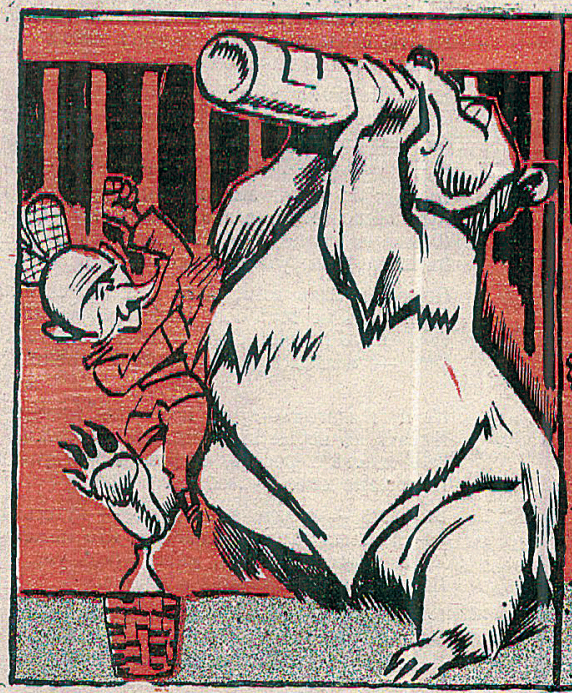

"Я его и водку выучиль пить: Отъ нея онъ еще смирнье становится"



И вотъ произошло то, что рыдко происходитъ съ ручными звьрьми и ихъ укротителями. Медвьдь оказалея на свободь, а царь въ кльткь. Подробности излишни.

Fig. 7. Radakov, Aleksandr. "Istoriia smirnogo medvedia i vesiologo tsaria". Novyi satirikon 15 (1917): 8

eshche! / A tam, iz t'my — / Sonmy i polchishcha / Takikh, kak my. // Poluraskosaia / Stal'naia shchel'. / Dikimi kosmami / Ot plech - metel. // - Vo imia Gospoda! / Vo imia Razuma! — / Ved' i korosta my, / Ved' i prokaza my! // Volch'imi iskrami / Skvoz' v'iuzhnyi mekh - / Zvezda rossiiskaia: / Protivu vsekh!" [“Af- 


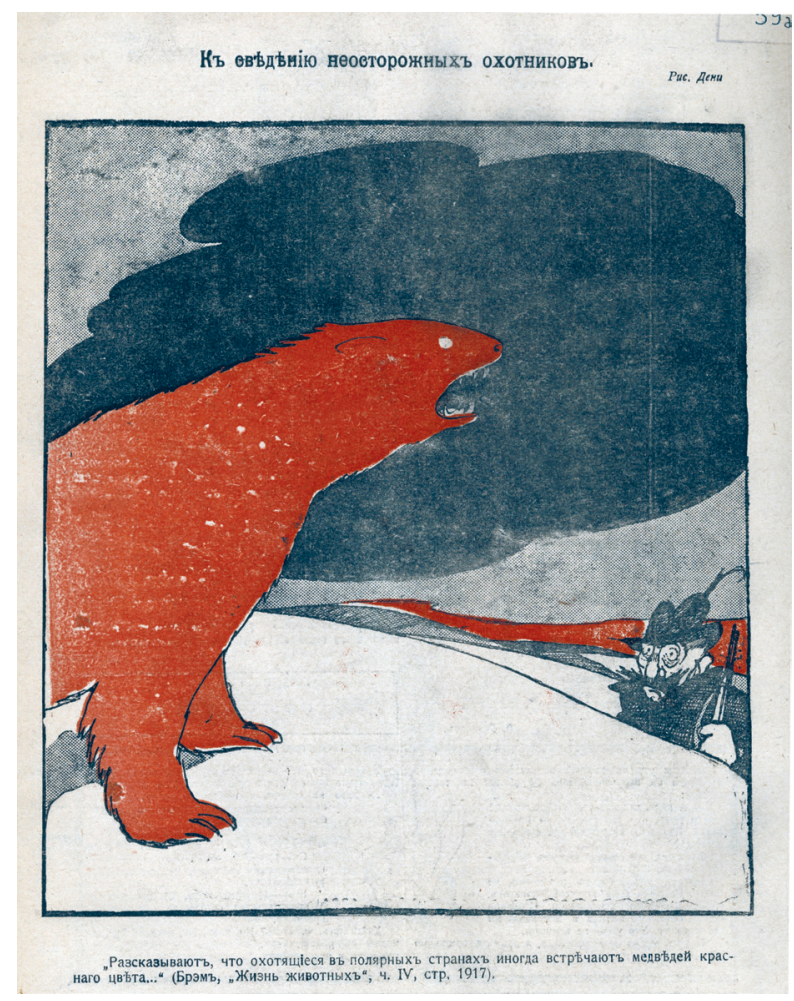

Fig. 8. Deni. "K svedeniiu neostorozhnykh okhotnikov." Bich 6 (1917): 16

perception of the bear as Russia's allegory - the image was now used to demonstrate her impotence. The comic effect was achieved by contrasting the bear's size with its weakness and inability to stand up to the German eagle [for instance: XVIII, p. 16].

After the October Revolution Bolshevik satirical journals emerged (including Krasnaia kolokol'nia, Gilotina, Krasnyi d'iavol, Solovei, and Grubian); as a rule, they lasted not more than several months due to various difficulties, above all financial and personnel constraints. We have not found any picture of the Russian bear in them ${ }^{21}$, and this

ter all, we are the bears! / After all, we are the Tatars! / Lice eaten / We go - bringing fires with us! // So far - behindhand! / And then, from the darkness - / Hosts and hordes / Of the same as us. // A halfsquinty-eyed / Slit of steel. / With a wild fell of hair / A blizzard from the shoulders. // - In the name of the Lord! / In the name of Reason! - / After all, we are the scab, / After all, we are the leprosy! // Wolfish sparks / Through the blizzard fur - / The Russian Star: / Against everyone!"] [29]. Tsvetaeva's lines "After all, we are the bears! / After all, we are the Tatars!" are certainly an allusion to Alexander Blok "Yes, we are the Scythians // Yes, we are the Asians", but the mood here is completely different. Tsvetaeva considered death and mass emigration from Russia not only as a Russian tragedy, but ultimately as a global one [30, p. 283]. The bear symbol is placed among other images of total Otherness: Asian nature, anti-Westernism, barbarism, aggression, and despotism. We do not see any positive connotations of the bear image in this poem. Its set of metaphorical associations includes the "Tatars", "a half-squinty-eyed slit of steel", "lice", "leprosy", "wild character", "fires", "hordes", "universal scourge", "patricide", "firing squad", and "blizzard". The bear-like features of the Russian people, if acknowledged, are by no means a cause for national pride.

${ }^{21}$ However, the main Bolshevik newspaper published Demyan Bedny's fable "The help" that recalled how a Whale (obviously, Great Britain) had betrayed his ally, the Bear, who used his last ounce of strength to fight the Elephant (Germany) [XIX]. 


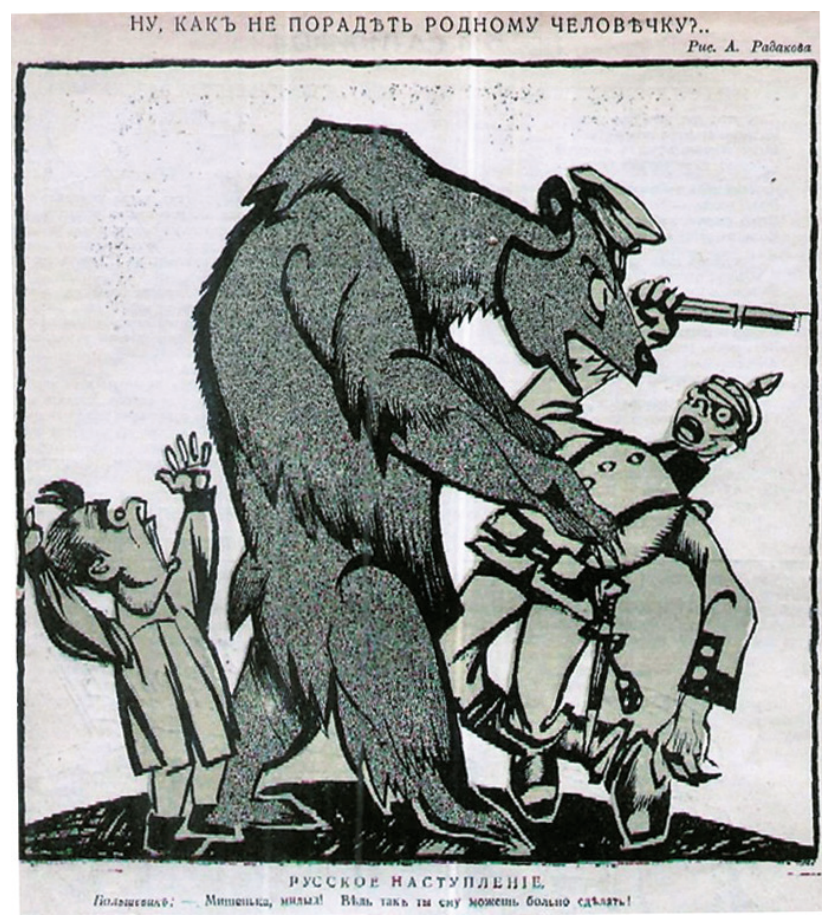

Fig. 9. Radakov, Aleksandr. "Nu, kak ne poradet' rodnomu chelovechku?". Novyi satirikon 26 (1917): 12

was hardly accidental. Orlando Figes and Boris Kolonitski, analyzing how contenders for power fought for the right to control the symbolic system of the revolution, suggest a distinction between "language of inclusion" and "language of exclusion" in Russia in 1917 [31, p. 116]. The former is characteristic of populist discourse, the latter of Bolshevik discourse, and the bear was an element of the former. Another important change was gradual closure of satirical journals that were close to "counterrevolutionary" parties. According to the authors of one book published in the Soviet era, "taking advantage of the freedom of press that was granted to the revolutionary people, bourgeois newspapers and magazines continued to poison minds and sow confusion in the people's consciousness, to smear the streams of lie and calumny at the working class and its party. All kinds of 'barabans', 'trepachs,' 'pugachs', and the like stinking offspring of Novyj satirikon and Bich turned into openly libeling editions. $\langle\ldots\rangle$ by the end of August of 1918 every possibility of renewal of this press in the country was totally eliminated" [32 $]^{22}$.

The caricature published in one of these journals, Trepach, in February 1918, was indicative of the bear's becoming the national allegory [XX, p.9]. The journal issue poked fun at the new authorities' numerous problems: criminality, anarchy, economic destruction, and demoralization of the army, and the caricature deals with events near Pskov and Narva when the German army resumed its advance against Petrograd after the collapse of negotiations in Brest-Litovsk, and Bolshevik efforts to organize the de-

22 At the end of 1918, in Moscow and Petrograd alone the new authorities closed 337 periodicals (150 in Moscow and 187 in Petrograd) [33, p. 22-3]. 
fense of the capital found little support among the population. The author of the caricature mockingly referred that "...the defeatists in vain detained Russia that was aroused as one," emphasizing that some regiment comprised fifty-three soldiers and in some train even thirty-three men raced towards the enemy of the Fatherland. The title "From the forthcomming history written by Ilovaiskii" probably aimed to demonstrate that Soviet propagandists (and historians) shamelessly distorted facts of the new reality; the drawing shows a runaway of a polar bear from the front, whom a "defeatist" tries to hold in vain. In the context of our study, it is noteworthy that "Russia that was aroused as one" is symbolized by a mighty bear; this image became a comprehensible, legitimate allegory of the country.

\section{Conclusion}

Summing up, we note that the use of the image of the bear was part of struggle for interpreting Russia's revolutionary events, and this struggle was carried out in no small part in caricatures published in satirical journals of four countries. Streicher notes that unlike speech makers and writers, who are concerned with discursive reasonings and arguments, the caricaturist as an image-maker aims at a purposeful condensation of sometimes complex meanings into a single configuration, a "striking image" [1, p. 440]. This condensation in one image becomes an effective weapon of political struggle, employed by all actors of symbolic politics in the reporting period.

The use of the "striking image" of the bear helped caricaturists express the essence of their understanding of political events in one drawing. Viewers could build an understanding of what was going on. The journals could exert influence over the situation, competing in the symbolic struggle. The metaphor served as a basic mechanism used by common people to simplify the world and to bring it closer to their own life experiences. At the same time, it not only aided understanding of political events; by allowing us to focus on one aspect of a concept (e. g., the battling aspects of arguing), a metaphorical concept can also keep us from focusing on other aspects of the concept that are inconsistent with that metaphor [34]. For this reason metaphors possess significant manipulative potential, which would explain their wide use in political rhetoric that is even greater as their impact on human thinking and behaviour is largely invisible [35, p. 7]. Metaphors occupy an important place in representations of foreign politics, which entailed the semiotic nature of international relations [36]. George Lakoff, examining representations of the Gulf War, illustrates the effectiveness of the use of metaphors in discourse on international relations with a famous phrase: backed up by bombs, metaphors can kill [37, p. 25-32]. Obviously, a special suggestive force belongs to the visual metaphors that are reflected in caricatures [38, p. 75-95].

According to Anthony Cohen's well-known characteristics, symbols do not so much express meaning as give us the capacity to make meaning [39, p.15]. From this perspective, every symbol is polysemantic; this is especially true regarding such an ancient and contradictory symbol as the bear. In caricatures of this period, this symbol carried various meanings: strength, power, cruelty; archaism, clumsiness, inability to develop; stupidity, greed, subjection, obedience, dependence, suffering; a force of nature, naturalness, rebellion; peacefulness, simplicity, sincerity. This polysemy of the symbol provided for the possibility to exploit it both for positive and negative assessments. 
The interpretations of the Russian bear in journals of the four countries varied, depending on their political orientation, relations of their countries with Russia in the course of the war, and political dynamics of revolutionary processes in Russia. While for Russian caricaturists, the revolution was a central event of this period, European observers perceived it through the prism of Russia's participation in World War I (and Polish artists also in the context of the struggle for national independence). Regardless of these differences in representations of the revolution through the prism of the bear metaphor, all had one thing in common: this metaphor was employed to symbolize Russianness both positively and negatively.

Finally, the image of Russia in the European satirical discourse practically throughout the Great War was inspired by linguistic and visual schemes that solidified before 1914 . Their strength was in their recognizability and capacity to refer to the tsarist country, which were deeply rooted in the collective imagination. Caricaturists employed traditional imagery of the bear themes: dancing bear, the training of the bear, bear-baiting, hibernation of the bear, bear's awaking, bear in snares, etc. As for Russia, we see an increased interest in the "Russian bear," although its ambivalence in Russian culture, as well as the predominantly negative values attributed to it in Western discourse, significantly limited the possibility of turning it into a national symbol ${ }^{23}$.

\section{References}

1. Streicher, Lawrence H. "On a Theory of Political Caricature". Comparativem Studies in Society and History 9, no. 4 (1967): 427-45.

2. Vipper, Boris. Vvedenie v istoricheskoe izuchenie iskusstva. Moscow: Izobrazitel'noe isskustvo, 1985. (In Russian)

3. Gombrich, Ernst H. "The Cartoonist's Armoury”. In Gombrich, Ernst H. Meditations on a Hobby Horse and Other Essays on the Theory of Art, 127-42. $2^{\text {nd }}$ ed. London: Phaidon, 1971.

4. Algarotti, Francesco. "Lettere sulla Russia". In Opere scelte, 5-144. 3 vols. Milano: Dalla Società Tipografica de’ Classici Italiani, 1823, vol. 3.

5. Lazari, Andrzej, de, Oleg Riabow, and Magdalena Zakowska. Europa i niedźwiedź. Warszawa: Centrum Polsko-Rosyjskiego Dialogu i Porozumienia, 2013.

6. Rossomakhin, Andrei, and Denis Khrustalev. Russkaia medveditsa, ili Politika i pokhabstvo. St. Petersburg: Krasnyi matros, 2007. (In Russian)

7. Khrustalev, Denis. "Proiskhozhdenie 'russkogo medvedia". Novoe literaturnoe obozrenie [Russian Studies in Literature], no. 1/107 (2011): 137-52. (In Russian)

8. Shepard, Paul, and Barry Sanders. The Sacred Paw: the Bear in Nature, Myth, and Literature. Afterword by Gary Snyder. New York: Viking, 1995-1985.

9. Bieder, Robert E. Bears. London: Reaktion Books, 2005.

10. Brunner, Bernd. Bears: A Brief History. Translated by Lori Lantz. New Haven: Yale University Press, 2009.

${ }^{23}$ An indirect evidence of this low significance of the bear image within the symbolism of prerevolutionary Russia, we find the attitude to this symbol during the post-revolutionary period, in the Soviet state of the 1920s. Soviet culture developed its own symbolism, which needed, first of all, to exclude symbols from the former exploitative system. This explains, for example, the highly negative attitude to the image of the eagle. Second, given the class, rather than the national nature of communist ideology and the Soviet state, the new symbolism was designed to eliminate national symbols. Thus, the very concept of Motherland was withdrawn from the political language of the USSR until its revival in 1934 in the form of the "Soviet Motherland." It would be reasonable to assume that if a bear had truly been perceived as a symbol of the Russian Empire or the Russian people, then it would not have had any chance of being included in Soviet political language of the 1920s. Meanwhile, in 1924, two satirical magazines called Medved' were published in Ulyanovsk and Ishim, and in 1929, the first issue of Severnyi Medved' was published in Yaroslavl. 
11. Dittmer, Jason N. "European Re-Union: Representations of Eastern Europe in NATO and EU Expansion”. PhD diss., Florida State University, 2003.

12. Utkin, Anatolii. Uinston Cherchill'. Moscow: Algoritm; Eksmo, 2002. (In Russian)

13. Marks, Karl. "Russkaia politika po otnosheniiu к Turtsii. - Rabochee dvizhenie v Anglii”. In Marks, Karl, and Fridrikh Engel's. Sochineniia. Prepared by Institut marksizma-leninizma pri TsK KPSS, 16879. 50 vols. $2^{\text {nd }}$ ed. Moscow: Politizdat, 1957, vol. 9. (In Russian)

14. Wolff, Larry. Inventing Eastern Europe. The Map of Civilization on the Mind of the Enlightenment. Stanford: Stanford University Press, 1994.

15. Neumann, Iver B. Uses of the Other: "The East" in European Identity Formation. Minneapolis: University of Minnesota Press, 1999.

16. Malia, Martin. Russia under Western Eyes: From the Bronze Horseman to the Lenin Mausoleum. Cambridge, MA; London: The Belknap Press of Harvard University Press, 1999.

17. Hudabiunigg, Ingrid. “Der 'Russische Bär' - redivivus?”. In Narrative Konstruktion nationaler Identität, Hrsg. Eva Reichmann, 251-81. St. Ingebert: Röhrig Universitätsverlag, 2000.

18. Kantor, Karl. "Kentavr pered Sfinksom." In Gorbachev-fond, Tsentr problem kul'tury. Kentavr pered Sfinksom (germano-rossiiskie dialogi), compiled and edited by Karl Kantor, 38-59. Moscow: Aprel'-85, 1995. (In Russian)

19. Kiustin, Adol'f, de. Rossiia v 1839 godu. Translated by Vera Mil'china and Irina Staf. 2 vols. Moscow: Izd-vo Sabashnikovykh, 1996, vol. 1. (In Russian)

20. Riabov, Oleg, and Andrzej de Lazari. "Misha and the Bear. The Bear Metaphor for Russia in Representations of the 'Five-Day War"'. Russian Politics \& Law 47, no. 5 (2009): 26-39.

21. Demm, Eberhard. "Propaganda and Caricature in the First World War". Journal of Contemporary History 28, no. 1 (1993): 163-92.

22. Tsykalov, Dmitry. "Obraz 'russkogo medvedia' v otechestvennoi karikature perioda Pervoi mirovoi voiny (iul' 1914 - fevral' 1917)" ["Image of "Russian bear" in Russian caricature during the First World War (July 1914 - February 1917)”]. Labirint: Zhurnal sotsial'no-gumanitarnykh issledovanii [Labyrinth: Journal of Social and Humanities Research], no. 4 (2013): 68-80. (In Russian)

23. Altick, Richard D. Punch: The Lively Youth of a British Institution, 1841-1851. Columbus; Ohio: Ohio State University Press, 1997.

24. Krzyżewski, Tadeusz. "Weterani lwowskiego czasopiśmiennictwa humorystycznego: z dziejów polskiej prasy w Galicji 1834-1918”. Rocznik Historii Czasopiśmiennictwa Polskiego 15, no. 2 (1976): 171-204.

25. Garsiia Sala, Ivan. 'Otgoloski medvezhiego rychaniia: Rosiiskaia imperiia kak belyi medved' v ispanskoi presse". In Russkii medved': istoriia, semiotika, politika, edited by Oleg Riabov and Andrzej de Lazari, 140-9. Moscow: Novoe literaturnoe obozrenie, 2012. (In Russian)

26. Riabov, Oleg. "The Symbol of 'Mother Russia' Across Two Epochs: From the First World War to the Civil War." In Russian Culture in War and Revolution, 1914-22. Book 2: Political Culture, edited by Murray Frame, Boris Kolonitskii, Steven G. Marks and Melissa K. Stockdale, 73-98. Bloomington, IN: Slavica Publishers, 2014.

27. Kornakov, Pavel. "Simvolika i ritualy revoliutsii 1917 g." ["Symbolism and Ritual in the 1917 Revolution"]. In Anatomiia revoliutsii. 1917 god v Rossii: Massy, partii, vlast' [The Anatomy of Revolution], edited by Vladimir Cherniaev, 356-365. St. Petersburg: Glagol, 1994. (In Russian)

28. Rossomakhin, Andrei. "Progermanskii Iuda". Istorik, no 7-8 / 31-32 (2017): 70-3. Accessed February 8, 2019. https://историк.pф/journal/прогерманский-иуда/. (In Russian)

29. Tsvetaeva, Marina "Pereselentsami”. Nasledie Mariny Tsvetaevoi. Accessed December 20, 2018. http:// www.tsvetayeva.com/poems/pereselencami.php. (In Russian)

30. Shveitser, Viktoriia. Byt i bytie Mariny Tsvetaevoi. Moscow: SP "Interprint”, 1992. (In Russian)

31. Figes, Orlando, and Boris Kolonitski. Interpreting the Russian Revolution. The Language and Symbols of 1917. New Haven: Yale University Press, 1999.

32. Stykalin, Sergei, and Inna Kremenskaia. Sovetskaia satiricheskaia pechat' 1917-1963. Moscow: Gospolitizdat, 1963. (In Russian)

33. Molchanov, Leonid. Gazetnaia pressa Rossii v gody revoliutsii i Grazhdanskoi voiny (okt. 1917-1920 gg.). Moscow: Izdatprofpress, 2002. (In Russian)

34. Lakoff, George, and Mark Johnson. Metaphors We Live By. Chicago: University of Chicago Press, 1980. (Russ. ed.: Lakoff, Dzhordzh, and Mark Dzhonson. "Metafory, kotorymi my zhivem”. Translated by Nikolai Pertsov. In Teoriia metafory, edited by Nina Arutiunova and Marina Zhurinskaya, 387-415. Moscow: Progress, 1990). 
35. Steuter, Erin, and Deborah Wills. At War with Metaphor. Media Propaganda and Racism in the War on Terror. Lanham: Lexington books, 2008.

36. Smirnov, Dmitrii. "Semiotika mezhdunarodnykh otnoshenii: gendernoe izmerenie (k postanovke problemy)" ["Semiotics of the international relations: gender dimension (Stating the problem)"]. Zhenshchina $v$ rossiiskom obshchestve [Woman in Russian Society], no. 4 (2018): 60-70. (In Russian)

37. Lakoff, George. "Metaphor and War: The Metaphor System Used to Justify War in the Gulf". Peace Research 23, no. 2/3 (1991): 25-32.

38. El Refaie, Elisabeth. "Understanding Visual Metaphor. The Example of Newspaper Cartoons". Visual Communication 2, no. 1 (2003): 75-95.

39. Cohen, Anthony P. The Symbolic Construction of Community. London; New York: Routledge, 1985.

\section{Sources}

I. Raven-Hill, Leonard. "Love me, love my cub". Punch 167 (July-December, 1924): 423 Accessed February 8, 2019. https://katalog.ub.uni-heidelberg.de/cgi-bin/titel.cgi?katkey=900370379.

II. Romanowicz, Antoni. "Pas a pas". Sowizdrzał 11 (1917): 1.

III. Raven Hill, Leonard. "In the grip. Portrait of any Austrian general on the Eastern front". Punch 151 (July-December, 1916): 135. Accessed February 8, 2019. https://archive.org/details/ punchvol150a151lemouoft/page/572.

IV. Partridge, Bernard. "Betrayed". Punch 153 (July-December, 1917): 399. Accessed February 8, 2019. https://archive.org/details/punchvol152a153lemouoft/page/n873.

V. “Jak się masz bolszewiku!”. Szczutek 5 (1918): 4.

VI. “Bajka - niebajka”. Szczutek 6 (1918): 4.

VII. Ly, John. "Niewdzięczna trzoda”. Szczutek 17 (1918): 4-5.

VIII. Ly, John. "Bolszewizmowi”. Szczutek 12 (1918): 5.

IX. Barski, Leonard. "Ostrożnie”. Mucha 26 (1917): 1.

X. "Die russische Offensive erfordert erst noch eine Umwälzung", Kikeriki 22 (1917): 8.

XI. "Ein kritischer Moment". Der Wahre Jacob 822 [2] (1918): 1. Accessed February 8, 2019. https://digi.ub.uni-heidelberg.de/diglit/wj1918/0013/image.

XII. "Die Ententeverbrecher und der russischer Bär". Kladderadatch 38 (1918): 11.

XIII. Sangurskii, P. “[No title]”. Budil'nik 16 (1917): 10.

XIV. Anonymous. "[No title]". Shut 48b (1905):2-3

XV. Shatan, D. “Zakliuchenie soiuza”. Svistok 2 (1906): 16.

XVI. Anonymous. “[No title]”. Pugach 9 (1917): 5.

XVII. Lutkovskii, L. “Svoboda, ravenstvo, bratstvo i russkii medved”'. Bich 33 (1917): 14.

XVIII. Radakov, Aleksandr. "Ne suli zhuravlia v nebe”. Novyi satirikon 40 (1917): 16.

XIX. Bednyi, Dem'ian. "Pomoshch". Pravda, December 31, 1917.

XX. Anonymous. "Iz budushchei istorii Ilovaiskogo". Trepach 3 (1918): 9.

Received: December 01, 2018

Accepted: February 21, 2019

Author's information:

Andrzej de Lazari - Dr. Habil., Professor Emeritus; alazari@toya.net.pl Oleg V.Riabov - Dr. Habil., Professor, Leading Researcher; riabov1@inbox.ru

Magdalena Zakowska — PhD, Associate Professor, Researcher; magdazakowska@hotmail.com 